\title{
Frequent cases force China to face up to scientific fraud
}

Six high-profile cases of scientific misconduct over eight months: for China's biomedical research, still struggling for global credibility, the frequent accusations of plagiarism, falsified data and fabricated resumes spell ๖ out a serious warning - one that the government is finally preparing to heed.

Chinese universities have traditionally failed to investigate or even acknowledge cases of misconduct. But in early March, Beijing-based Tsinghua University fired Hui Liu, a professor of medicine, after he was found to have claimed another researcher's papers as his own on his resumé. Then, in late June, Tongji University in Shanghai dismissed Jie Yang, dean of the university's school of life sciences, for allegedly stealing his colleagues' data.

The Ministry of Education also in May set up a research ethics committee to discipline researchers, and the Ministry of Science and Technology has proposed measures such as the random selection of grant reviewers to combat nepotism.

Most recently, Yong Shang, China's vice minister of science and technology, announced on 10 July that the ministry plans to set up an independent agency to monitor the research projects it funds.

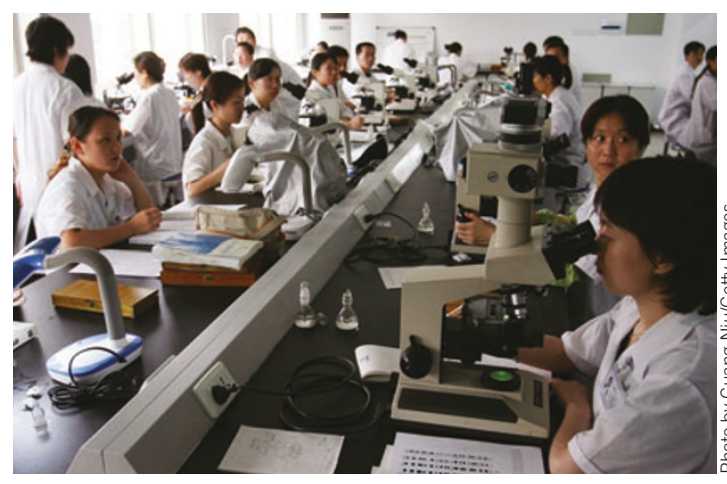

Pressure cooker: Fierce competition for funds may be contributing to a rise in cases of scientific misconduct.

In total, more than 10 cases of misconduct have surfaced in the past year in fields ranging from information technology to biomedical research. But research in the life sciences may be particularly susceptible to fraud because it is often difficult to reproduce exactly, says Shimin Fang, a former biochemistry researcher. Fang now runs a website called New Threads (www.xys.org) that lists allegations of fraud and identified five of the six cases, including that of Hui Liu.

In the rush to succeed, China has not set up a robust system to adequately manage and audit grants and to safeguard against misconduct, says Yigong Shi, professor of molecular biology at Princeton University. The pressure to secure grants may have led some scientists to fabricate research, he says. "Previously, the funding and the level of competition in the field were much lower."

China's investment in life sciences has grown as much as $400 \%$ in the past five years to RMB13 billion (US $\$ 1.6$ billion).

China's large pool of patients and cheap skilled biotech researchers have been highly attractive for collaborators outside China, but the recent incidents have struck a note of caution for Chinese scientists abroad.

"We have heard some rumors before, and with the cases, we would be particularly cautious when cooperating with our domestic counterparts," says Hong Lu, a researcher at Kansas University Medical Center.

To restore their confidence, the government should routinely investigate allegations of misconduct and openly discipline those found to be guilty, researchers say.

In the long term, adds Princeton's Shi, China must also develop other measures of success rather than rely exclusively on publications in journals with high impact factors. "When the funding and rewards are endowed to the true scientific excellence," he says, "fraud in life science can be largely avoided."

Hepeng Jia, Beijing

\section{Rules murky on DNA-based identification of disaster victims}

Any research involving people requires that scientists go through a lengthy process of getting informed consent and approval from ethics panels. But does testing techniques on dead people constitute research? That question has stumped scientists who have tried to use new methods to identify victims of disasters.

After the events of 11 September 2001, scientists went through the proper channels to study the day's impact on survivors. But it never occurred to those leading the identification of the victims that their project required approval.

New York City's office of the chief medical examiner led the identification project, the largest ever to use DNA profiling. Robert Shaler, then the agency's director of forensic biology, says the project shouldn't have needed approval because investigating deaths is the office's mission.

The US National Institutes of Health (NIH) thought otherwise.

Shaler had suggested using single-nucleotide polymorphisms (SNP), or minor variations in genes, to analyze extremely degraded DNA fragments found at the World Trade Center site. Because the use of SNPs was still novel at the time, members of NIH's advisory board thought the project required approval from an institutional review board (IRB).

"They said we needed IRB approval because we were using new technology," says Shaler, now director of forensic science at Penn State University. But "these [were] not human subjects, it's not doing research on human subjects."

In the end, the disagreement didn't slow identifications. Shaler applied for approval and the city health department's IRB sided with him, waiving approval in August 2003. The first SNP identification was made that December, and SNPs produced 20 of the 850 identifications made based solely on DNA results. Scientists eventually identified 1,594 people using DNAbased techniques and more traditional forms of identification, such as dental records.

The experience, says Shaler, is a clear illustration that research agencies must clarify what constitutes human subject research- particularly during disasters.

The NIH declined repeated requests for comment on the topic. But the Department of Health and Human Services, the NIH's parent agency, doesn't view the use of new technology to identify disaster victims as research, says Christina Pearson, a spokeswoman. The agency only requires IRB approval for work on living individuals, she says.

The NIH scientists clearly misunderstood US research regulations, says Arthur Caplan, director of the University of Pennsylvania's Center for Bioethics. "This is the clearest example I've heard of in a long time of what is not research."

Approval from an IRB wasn't an issue after Hurricane Katrina, because scientists were able to use standard forensic methods.

Ideally, scientists would use new technologies before a disaster occurs, Shaler says, but the federal government must prepare for other possibilities. "These things should be automatic," he says. "We shouldn't have to jump through hoops."

Alisa Opar, New York 